\title{
Different Diasporas and the Hype of Hybridity
}

\author{
Katharyne Mitchell \\ 1997. Environment and Planning D: Society and Space 15 (5), 533-53. ${ }^{1}$
}

This is the historical movement of hybridity as camouflage, as a contesting antagonistic agency functioning in the time lag of sign/symbol, which is a space inbetween the rules of engagement.

- Bhabha, 1994, 193

Today's self-proclaimed mobile and multiple identities may be a marker not of contemporary social fluidity and dispossession but of a new stability, selfassurance and quietism.

In much of contemporary cultural criticism there is a celebration of diaspora and hybridity as spaces of subversion. The terms are attractive because of the inherent instability associated with each concept. In contrast with the unappealing teleologies of modernist paradigms or the paralyzing binaries of either/or frameworks, hybridity and diaspora seem to offer a satisfyingly unstable and ambivalent alternative. For many poststructuralist critics, conceptualizations of the mobile, marginal, contradictory, and ambiguous are especially soothing in a period where a growing number of Marxist and feminist scholars have demanded locations of actual resistance in addition to positions of textual critique. The "third space"

${ }^{1}$ Reprinted with permission from Katharyne Mitchell, first published in Environment and Planning D: Society and Space, 1997, 15, pp. 533-553, Pion Limited, London.

2 Editors' note: third space, in this context, is an in-between conception of space, which mediates between the "first space" of concrete and material circumstances and the "second space" of 
have been offered to the sacred altar of resistance as new sites of hope. These liminal spaces are theorized as important positions in the tactical war against dominant hegemonies. In particular, they are conceptualized as key sites of intervention in narratives of race and nation and as the chiasmatic spaces of a progressive and liberatory transnational culture.

I would like to draw out some assumptions implicit in these analyses and offer a partial critique of this growing body of literature. Without denying the potential for resistance, I critique the notion that the diasporic, the liminal and the hybrid can always be equated with a politically progressive agenda. I argue that the focus on linguistic and cultural disruptions to hegemonic norms, and the implicit assumption of the nation as an abstract cultural space with borders which "contain" lands which must be crossed or "translated" in order to intervene in the ongoing narration of the nation, obscures the importance of contemporary economic processes and of various kinds of diasporic, deterritorialized, and hybrid subject positions that can be and have been used strategically for economic gain. In other words, liminal and partial sites can be used for the purposes of capital accumulation quite as effectively as for the purposes of intervention in hegemonic narratives of race and nation.

Just as it is necessary to situate any discussion of hybridity and diaspora within history [...], it is also critical to locate the concepts geographically. The overuse of abstract metaphors [...] often leads to thorny problems of fetishization. As concepts such as hybridity become disarticulated from the historically shaped political and economic relations in which identities and narratives of nation unfold, they take on a life and trajectory of their own making. Second and third readings, borrowings, interventions, elaborations - all can contribute to conceptualizations that are not only completely removed from the social relations of everyday life, but which also, because of this very abstraction, become ripe for appropriation. The disingenuous move of the "third space" is to occupy a position "beyond" space and time, and beyond the situated practices of place and the lived experience of history. ${ }^{3}$ The space thus satisfyingly transcends the kinds of essentializing locations that characterize a certain branch of work in historical materialism and feminism. But without context, this "in-between" space risks becoming a mobile reactionary space, rather than a traveling site of

mental and imagined representations, and which exposes practices of exclusion while offering possibilities for liberation.

${ }^{3}$ Soja's recent book is a case in point. In this work the "Thirdspace" is called upon to heal all of the theoretical rifts and "binarisms" of the last several centuries, as well as to open up our spatial imaginations through a critical strategy of "thirding-as-Othering" $(1996,5)$. This space is able to accomplish all of these marvelous things, precisely because it does not actually exist. Lavie and Swedenburg (1996, 16-23) have expressed a similar [enamouring with] the thirdspace concept, although with considerably more attention to the historical politics of location. Nevertheless, they too conjure up a notion of space relying more on psychoanalytic and cultural narratives than the "geographies" of identity to which they refer in their title. I am indebted to Donald Moore for his insights here. 
resistance. It is this problem of appropriation, particularly with reference to economic processes and agents, that I wish to investigate further in this paper.

\section{Diaspora and Hybridity}

In the past, the invocation of diaspora has related most specifically to the situation of a people living outside of their traditional homeland. Historically, for example, the general dispersion or scattering of a "diasporic" people has been identified most closely with the dispersion of Jews among the "Gentile" nations. ${ }^{4}$ In contemporary usage in much of cultural theory, however, the term has come to signify a more general sense of displacement, as well as a challenge to the limits of existing boundaries. ${ }^{5}$ The tighter definitions that signified specific groups as diasporic, or which followed an ideal-type model in which certain features taken together signified diasporas have, by and large, given way to broader conceptualizations of travel, displacement, dislocation, and divided loyalties. ${ }^{6}$ Clifford (1994), among others, has offered a useful contemporary critique of the kinds of constraints imposed by the normative assumptions of ideal type models. Although the attempt to define diaspora is important, it limits our understanding of the "ambivalent, even embattled" signifiying features of diasporic groups. It also elides the [historical] process of change, wherein different societies "wax and wane in diasporism, depending on changing possibilities" (Clifford, 1994, 306).

\section{$[\ldots]$}

[T] here is a powerful critique of prior narratives of fixity and mobility, and the power relations involved in them. This broad conceptual understanding of the ways in which the invocations of diaspora can have critical material and symbolic effects has provided a crucial impetus for scholars to further their research into the roots and

\footnotetext{
${ }^{4}$ See, for example, the definition of the Oxford English Dictionary (shorter edition).
}

${ }^{5}$ Lavie and Swedenburg write, "The phenomenon of diasporas calls for reimagining the 'areas' of area studies and developing units of analysis that enable us to understand the dynamics of transnational cultural and economic processes, as well as to challenge the conceptual limits imposed by national and ethnic/racial boundaries" (1996, 14; see also Gilroy, 1992).

${ }^{6}$ Safran $(1991,83-84)$ has written a defining model of diaspora, in which he lists six key features. These include a history of dispersal, memories of a place of origins, alienation in the new country, a desire to return to the homeland, ongoing support of the homeland, and a sense of collective identity as a group. Within the confines of this somewhat restrictive definition, he identifies just seven contemporary diasporic populations. For many contemporary theorists, this approach is far too narrow, and prescriptively limits both the epistemological potential of the term, as well as the possibilities of differently framed "diasporas" such as those of the [B]lack Atlantic, so persuasively described by Gilroy (1993; see also Clifford, 1994, 305). 
routes of specific diaspora histories and geographies. Despite the imperative to contextualize, however, many contemporary postructuralist theorists have seized on the progressive theoretical potential of the term itself, and abstracted it away from the situated practices of everyday life. The identification of peoples who have multiple loyalties, move between regions, do not occupy a singular cultural space, and who often operate in some sense exterior to state boundaries and cultural effects, has proven attractive for theorists who have sought to disrupt normative narratives and understandings of nation and culture. Those in literal motion in-between nations or outside of proscribed, static cultural locations become vaunted as the potential locus of cultural understandings that resist hegemonic norms of both race and nation.

The same abstracting away from a situated historical perspective has also occurred in numerous discussions of hybridity. The standard dictionary definition of the term is of a thing derived from heterogeneous sources or composed of incongruous elements. Not surprisingly, this definition has proven attractive for those interested in questions of identity and the constitution of subjectivity in a postmodern era. Many cultural theorists herald the ways in which apparently hybrid subject positions can facilitate multivocal communications and the production of syncretic [i.e. combined] cultural forms. Owing to the manifest lack of an essentialized or fixed identity (through the derivation from heterogeneous sources and incongruous elements), the hybrid stands as the perfect conduit for postructuralist understandings of the advantages of pluralism, ambivalence and nonfixity. Because of its neither-nor nature, hybridity is celebrated as a process rather than a thing; its inherent resistance to fixed binaries causes it to remain in a perpetual state of flux, related to and yet not originating from or causing other moments, spaces, or entities. For many cultural theorists, it is this mobile undecidability that posits hybridity and hybrids as the perfect interlocutors of resistance to essentialist narratives.

With both diaspora and hybridity it is the spaces in the margins, the unfixed spaces in-between states and subject positions that are vaunted as the location of resistance and intervention in hegemonic narratives of race, culture and nation. Bhabha, for example, writes of the importance of the "turning of boundaries and limits into the in-between spaces through which the meanings of cultural and political authority are negotiated" and heralds the "international dimension both within the margins of the nation-space and in the boundaries in-between nations and peoples ..." (1990, 4, emphasis added). Bhabha posits hybridity as a form of in-between space, which he terms the "third space", a space inherently critical of essentialism and conceptualizations of original or originary culture. He writes, "For me the importance of hybridity is not to be able to trace two original moments from which the third emerges, rather hybridity to me is the 'third space' which enables other positions to emerge" $(1990,211)$.

\section{$[\ldots]$}

The emphasis on the cultural spaces of the nation - spaces which can be marked and then crossed - leads a geographer to the [...] critical question: what are the 
actual physical spaces in which these boundaries are crossed and erased? [...] A pertinent contemporary example of hybridity's glorification at the expense of the historical and material is evident in a recent article on hybridity in Hong Kong.

\section{The Hong Kong Hybrid in Diaspora}

We (as Hong Kong intellectuals) need to define our CCD [culture of critical discourse] from 'within' Hong Kong's hybridized culture which is at the same time within and without the legitimized 'purer' cultures, straddling a problematic position between the East and the West. (Lee, 1994, 18).

In Lee's work the Hong Kong intellectual is positioned as the perfect hybrid subject - one whose "mixed-code hybridized language" can aid in the "perpetuation of Hong Kong's culture as a hybridity" (1994, 21-22). It is both this linguistic liminality and the ambivalent position between national cultures (of China and Britain) which Lee believes enables new spaces of resistance and new kinds of interventions in the national narratives of "Great China" and "Western civilization." He writes,

Translation and mimicry produce a new hybridized subjectivity and culture which are precisely those of Hong Kong people. The role of Hong Kong intellectuals is to re/present such a subjectivity and culture, and their ambivalence, in order to deconstruct the illusion of cultural purity that many Hong Kong people still cling to: either the dead tradition of Great China, or the blind worship of Western civilization $(1994,19)$.

Lee argues that intellectuals who grew up in Hong Kong, and are either still in Hong Kong or have now emigrated to the West, would likely identify themselves as Chinese, or as a hybrid, or as "someone from Hong Kong - a purely geographical location devoid of national boundary and cultural identity" $(1994,12)$. The discussion of Hong Kong as a site "devoid of national boundary and cultural identity" is made in many places, as he discusses the territory's "lack of national identity" and cultural authenticity. As Hong Kong is depicted as a place in-between China and the West, without real national borders and thus without any national imagining of a common territory, tradition or origins, Lee posits Hong Kong people as subjects uncompromised by the myth of origins or the necessity to "perform" or supplement the nation.

In Lee's analysis, it is Hong Kong's politically ambiguous and culturally ambivalent situation that has created the potential for a progressive "hybrid" intervention. The tremendously successful capitalism of the colony, noted by most of the rest of the world, is mentioned only as one of the reasons that Hong Kong has been a blind spot for post-colonial discourse; in other words, because of its very success, it has deconstructed the "romanticization of the colonialism-wrecked East" $(1994,12)$ and thus provided unsuitable fodder for numerous postcolonial critics. The separation of the economic and the cultural in his analysis is most clearly marked in the 
discussion of language, where linguistic liminality is theorized as a site in-between, a space that allows and facilitates critiques of both Great China and Western civilization.

Yet this "third space" is clearly a space related to capital accumulation in a very literal sense. As the author notes himself, English is learned as a tool in Hong Kong - one that is strategically important for business and a "necessity for social mobility and white-collar employment" (1994, 13). It is this English, incompletely learned, or learned and manipulated that forms the "Chinglish" hybrid which Lee finds so subversive. Language is theorized here as a product of colonialism and capitalism, one that allows for an in-between subject positioning that may resist national narratives of authenticity and purity. Yet there is no conceptualization of how language may also be productive of spaces of colonialism and/or capitalism. Theorized in the abstract and culturally inscribed, a "hybridized vernacular" and "mixed-code language" is posited as inherently progressive because of its creolized nature. It is produced by economic and cultural forces, but then takes a position of antagonist ambivalence in an abstracted "third space". The economic provenance of this hybrid is lost, as is its potential to produce spaces that may be violent, retrogressive, or strategically materialist.

The problem is compounded by the notion of language as something that is chosen and wielded at will. As Poster (1990) and others have discussed at length, people are constituted by and through language. The belief that Hong Kong intellectuals can "define our CCD from 'within' Hong Kong's hybridized culture" and manipulate this hybrid discourse in politically progressive ways [...], neglects the ways in which the economic, cultural, political, and social threads woven into the very language of the "culture of critical discourse" infect the speaker and not just the words themselves. The notion of a culture of critical discourse, as Lee borrows it from Gouldner, ${ }^{7}$ abstracts away from the necessary situatedness of language and its imbrication in the economic as well as social practices of everyday life. ${ }^{8}$

The implicit notion of a progressive hybrid choice for the Hong Kong intellectual returns as Lee asks, "May Hong Kong intellectual be used as a strategic corrective to the polarizing binarism between 'Chinese intellectual' and 'the (Western) universal intellectual'"? He answers by suggesting that if this is possible it is through the popular_culture of Hong Kong, because it is popular culture which allows a "hybridization of Chinese and Western" and does not insist on the "purity of imagined cultural polarizations." Hybridity is again conceptualized in terms of contemporary

${ }^{7}$ Gouldner's definition: "a relatively situation-free discourse is conducive to a cosmopolitanism that distances persons from local cultures, so that they feel an alienation from all particularistic, historybound places and from ordinary, everyday life. ... The grammar of critical discourse claims the right to sit in judgement over the actions and claims of any social class and all power claims to truth, however different in social origin, are to be judged in the same way" (quoted in Lee, 1994, 12).

${ }^{8}$ For a further discussion of the economic and social situated ness of language, see Pred's (1990) brilliant ethnography of working-class life and language in Sweden at the turn of the century. 
cultural and linguistic boundaries - boundaries that the Hong Kong intellectual can choose whether or not to cross. By virtue of their inherently ambivalent national positioning, Hong Kong intellectuals can occupy the marginal spaces which allow them the critical cultural distance to resist hegemonic narratives of race and nation. This conceptualiz[es] [...] a cultural position able to "detach itself from self-serving interest or unquestioned, but strictly limited, ends." [...]

Without contextualizing both the specific movements and constitution of hybrid subjects, as well as the historical provenance of theoretical terms "within the ideologies of their times", it would be easy to position Hong Kong Chinese "hybrid" and "diasporic" emigrants to Canada as the perfect conduits for "supplementing" the nation and forcing the renegotiation of its cultural and political authority. It would appear that this group, among all others, could make substantial interventions in the narration of the nation as the archaic temporality of territory and tradition, and provide the perfect chiasmic location for a new transnational culture. ${ }^{9}$ But interventions in hegemonic nationalisms that are posited in cross-border or transnational, transcultural spaces are limited by their reliance on an abstract notion of preexisting space. For example, that national identity always originates and is supplemented in a nation-space is an assumption that doesn't always hold true. It could be argued that the origins myth, which Bhabha claims forms the roots of modern nations, is not necessarily singular (cf. Sparke, 1996, chapter 2) and not necessarily about a common spatial territory. ${ }^{10}$ For some contemporary Hong Kong Chinese citizens, for example, the foundation of national identity may be rooted in both historical memories related to China and also to the common spaces of capital accumulation located in Hong Kong itself. The strategic use of ethnic identity as a signifier of nationness (in this case 'Chineseness'), may not be entirely bound to literal roots in the sense of a rootedness in a common origin territory or nation-space, but may be bound more closely to another kind of location - one that privileges certain types of economic spaces, such as

9 To some degree, this type of "forced renegotiation" has taken place in Vancouver in the context of major struggles over municipal zoning. In one contestation that I examined in the early 1990s, an $\mathrm{AD}$ HOC neighborhood group formed primarily of recent Hong Kong immigrants, contested a downzoning measure in a formerly racially exclusive area of the city, Shaughnessy Heights. In the process of contesting the zoning, the group also exposed the types of racial exclusions that had formerly kept Chinese residents from equal participation in public hearings, such as those concerned with neighborhood zoning. In this way, the AD HOC committee effectively challenged the idea of equal access to the public sphere and forced a renegotiation of the actual workings of democracy within Canada's liberal welfare state. Despite this "liberatory" component, however, it is worth noting that the critique of the political workings of the liberal democratic process was made from a position of economic liberalism. The key argument of the AD HOC committee rested on an individual's economic freedom vis-à-vis private property. This case thus amply demonstrates the complexity of any given "resistance" to dominant narratives, and the need to contextualize and consistently monitor these liberatory sites (see Mitchell, 1997a; Ley, 1995).

${ }^{10}$ Clifford notes in this regard the early work of the Jewish anti-Zionist, Simon Dubnow, whose "secular vision of 'autonomism' projected a cultural/historical/spiritual 'national' identity beyond the territorial/political" (1994, 328). 
those of free market capitalism. It may also be a complicated mix of paradoxical or shifting allegiances and identities. It is only through an examination of particular histories and geographies that these issues can be understood with any clarity.

I examine these ideas by looking at some self-fashioning strategies of Hong Kong Chinese entrepreneurs who are engaged in business ventures in both 'Asia' and 'the West'. I focus first on one of the hegemonic narratives of the type which Bhabha, Lee, and others, wish to disrupt. This narrative, which was prevalent in Vancouver in the 1980s, is that of the literal rootedness of Anglo citizens in the physical spaces (soil) of the Canadian nation, a narrative which clearly excluded the recent Hong Kong immigrants to the city. I then discuss the counternarrative offered by the Hong KongCanadian business community, and look more broadly at some of the self-fashioning strategies of Hong Kong Chinese business-people as they operate in the "liminal" and diasporic sites in-between nations. Without denying the potential and indeed often realized resistance to many cultural narratives, such as that of rootedness, I foreground instead the ways in which counternarratives can be and are also used for the purpose of furthered economic integration and capital accumulation.

\section{Trees and the Roots of Nation}

There is probably no better symbol for British Columbia at this time than trees. Nice, big, old trees. It was through the mass destruction of hollies and sequoias in Vancouver's neighborhoods and on West Vancouver's hills that we all became aware of the fact that the Lower Mainland was changing. (Taylor, Vancouver Sun, 1991, A2)

People are often thought of, and think of themselves, as being rooted in place and as deriving their identity from that rootedness. The roots in question here are not just any kind of roots; very often they are specifically arborescent in form. (Malkki, 1992, 27)

It is odd how the tree has dominated Western reality and all of Western thought ... The West has a special relation to the forest and deforestation ... (Deleuze and Guattari, 1987, 18)

In Vancouver in the late 1980s, pervasive urban development led to major dislocations for numerous urban residents. Much of this development was related to voluminous capital flows from Hong Kong, as many Hong Kong capitalists sought secure locations for both capital investments and residence in Canada. ${ }^{11}$ Conflicts over

${ }^{11}$ For further discussion of the changes and conflicts in Vancouver during this time period see Mitchell (1993b). See also Olds (1995) for an analysis of the impact of urban megaprojects funded by Hong Kong dollars. 
rising house prices and apartment rents, housing and apartment demolitions, and the construction of large, "monster houses" became imbricated in a racial discourse, as many long-term Anglo residents associated the rapid transformation of the city with the increased immigration and investment from Hong Kong. ${ }^{12}$ One of the most bitter sites of contention was the removal of mature trees from the lawns and gardens of houses slated for demolition and rebuilding. Numerous community movements, such as the Kerrisdale-Granville Homeowners' Association (KGHA), quickly arose to combat the "destruction" of the landscape and to protest the loss of ambience and character in the west-side neighborhoods of Vancouver. ${ }^{13}$

In a neighborhood action against the felling of two giant sequoias in April, 1990 , members of the KGHA protested by tying yellow ribbons around the trees a few days before they were scheduled to be removed. The protesters joined hands around the trees and left informational placards where bypassers could read them. A month later, after the two sequoias had been felled, forty neighbors from the area planted new sequoias in a city park to commemorate the loss of the older trees. The community organization invited high-school students from two schools to help plant the new trees. Tom Arnold, a reporter from the Vancouver Sun, described the tree-planting event with the phrase, "“An eight-year-old boy helped turn the soil ...' Cindy Spellman said of the planting, 'It's worth it because we are planting the new trees for our children"” (Arnold, Vancouver Sun, 1990, B1).

The removal of mature trees and gardens in west-side neighborhoods caused greater anger and resistance than either the demolition of apartment buildings or the construction of the so-called monster houses. Trees were linked with an image of Vancouver that was extremely important for many Anglo residents to maintain. The tree-lined streetscape and even specific trees and gardens were identified with the essence of a west-side way of life; removal of the trees was threatening to this image and was fought with great vehemence. As Duncan and Duncan (1984) have written about Shaughnessy Heights, many of the west-side neighborhoods of the city were established in the image of a pastoral Britain of the pre-industrial era. The free-flowing landscaping and mature trees operated symbolically as a link to an imagined aristocratic past, but also as a bulwark against change, particularly the pernicious influences of change brought in from the outside. Canetti $(1978,84-85)$ writes of the forest:

${ }^{12}$ The term "monster houses" refers to a commonplace description of a number of extremely large, often box-shaped homes that were constructed in west-side areas in the 1980s and early 1990s. These houses were sources of major conflict, as they were perceived by many long-term residents as destroying the "character" of the neighborhood (see Mitchell, 1997b).

${ }^{13}$ Urban redevelopment transformed all of Vancouver in the late 1980s, but it was protested most vociferously in the upper-class, mainly Anglo neighborhoods of the city's west-side. 
Another, and no less important, aspect of the forest is its multiple immovability. Every single trunk is rooted in the ground and no menace from outside can move it. Its resistance is absolute; it does not give an inch. It can be felled, but not shifted. And thus the forest has become the symbol of the army, an army which has taken up a position, which does not flee in any circumstances, and which allows itself to be cut down to the last man before it gives a foot of ground.

As the trees were also considered to be living beings, their destruction was perceived in a particularly serious light. Resistance took on the character of a moral crusade. Those who destroyed trees were morally wrong or depraved; at the least they were misguided or uneducated. One activist protested the felling of two sequoia trees at 6425 Marguerite in Kerrisdale by invoking religious language in her speech at a neighborhood protest. She said dramatically, "These trees are part of the soul of the neighborhood" (Quoted in the Courier, 1990, 7). After their removal, a reporter described the remaining empty space in terms of death and burial, again recalling metaphysical imagery: "All that remains of what one horticulturalist called 'the most perfectly matched sequoias in Vancouver' is two earth-covered stumps" (Blain, Vancouver Sun, 1990, B4). ${ }^{14}$

Investing territory and things with human characteristics allows the naturalization of links between people and place. The connection between people and place - metaphorically expressed through tree imagery - is important not only in establishing, confirming, and romanticizing those who are "of the soil", who are part of a traceable, genealogical tradition, who "belong", but also in identifying and demonizing transients or sojourners arriving from elsewhere - those who are "without place". The condition of placelessness or rootlessness in society is perceived and represented as pathological - and described so in moral terms (Malkki, 1992).

The moral element of the fray was clearly linked to a positive depiction of "the country" and a negative image of "the city" (compare Williams, 1973). ${ }^{15}$ As a dichotomy between city and country morals and ways of living emerged, the Hong Kong Chinese often became identified as the essential city dwellers. These

${ }^{14}$ For a further analysis of this particular tree confrontation, see Ley (1995). The controversy over the removal of trees on private property has been ongoing, and remains one of the most divisive and bitter issues in Vancouver city politics.

${ }^{15}$ Of course this idea of the country and its ethically superior ways of life were promulgated from suburban residents well within municipal boundaries. The irony of the use of morality in the tree debate extends in several directions, including the fact that a number of the wealthy, west-side residents involved in this controversy may have secured their positions in these upscale, wooded neighborhoods as a result of the profits reaped from the BC timber industry. In addition, as Willems-Braun (1997) has shown with regard to the wider rhetoric surrounding the 'rainforest' and 'nature' in British Columbia, discourses such as these have completely excluded and/or appropriated the history, experiences, and voices of First Nations people, from whom the 'wooded' land was originally seized. 
cosmopolitan urbanites, carriers of the ill effects of accelerated modernism, were set up in opposition to and confrontation with those who "love gardens". Virginia Cohen, a west-side homeowner, said in an interview:

V: What I feel personally, I'm European, so I very much like the garden. Our garden stretches quite a ways so that it's actually balanced with the house. You know how the houses in Europe are in proportion with the garden in general. You look at Spain and France and Germany, it's been the same for years. Although people have come and added to it, it's kept that balance. That's my difficulty. I love to see the houses in proportion with the garden. The problem is, in Hong Kong they have very little land. Here they come and there's so much land and so what do they do? You see?

$\mathrm{K}$ : Is it changing so quickly that you have a sense that it's going to be different for your children?

V: Well my other area that I lived in between Oak and 41st and 49th, you wouldn't recognize it, it's completely changed. All the houses are torn down, and they were a right good size. But now they're huge, immense houses with very little garden. ... Because I really wonder if they love gardens (author's interview, 1990). ${ }^{16}$

In this statement, a past European heritage and an aesthetic sense of love for a wellproportioned garden is set up in contrast with the Hong Kong tradition, in which an inherent love of the garden is considered dubious. The love of the garden represents an old and venerable European way of life, a way of life which has "been the same for years." It conjures up images of large garden estates, rootedness, tradition, folk, soil, a past. ${ }^{17}$ The contrary image, of urban space and the lack of a proper "balance" of house and garden, distills meanings of rootlessness, sojourn, and transience. ${ }^{18}$ In specific neighborhood actions against tree removal, these images were invoked time and again, with the protection of mature trees coded as the protection of tradition, heritage, and a nostalgic, communally remembered past.

${ }^{16}$ Pseudonyms have been used to protect privacy.

${ }^{17}$ Here the imperial significance of well-balanced, well-tended gardens can be linked with the broader domestication of the landscape under colonialism. The "ideal" landscape thus is one that has been tamed by a "civilizing" force, yet which simultaneously erases the scars of that force through the promotion of equilibrium, stasis, and tradition. See, for example, Kolodny (1975) and Schaffer (1990).

${ }^{18}$ The negative depiction of the city and the linking of the city with a particular group of people was similarly employed against the Jews in [Nazi] Germany, when capitalist practices, Jewish lifestyles and immoral behavior were linked and located in an urban forum. See, for example, Theweleit (1987). 
Both nation and culture are conceived in these rooted, territorialized, and essentializing images and terms. Transience or "decontextualized" culture threatens to denature and spoil these images of self-identification (Deleuze and Guattari, 1987, 18; Malkki, 1992, 34). Uprootedness is strenuously resisted, particularly by those who already feel a threat to personal or national identity. The loss of an arborescent, genealogically traceable connection to the past is connected with the loss of an imagined future community. ${ }^{19}$ The emphasis on this connection between past and future is ritualized in the gesture of using a child in the tree-planting ceremony. The symbolism of using an eight-year-old to "turn the soil" reflects a perceived movement of time from the heritage and traditions of the past, to the children and community of the future. In this vision, those who control the past control the future.

Apart from the sense of continuity that is advanced in these types of actions, there is also an implicit connotation of the right to judge what are appropriate and inappropriate activities on the landscape. The right to participate in the production of the landscape and its associated symbolic meanings is one that is held only by certain populations. These populations, who are themselves identified as "rooted", maintain and reflect the "correct" sensibilities that are appropriate to the land. Historically, the ability to participate in landscape production is one that has been predicated on highly racialized and gendered grounds (see, for example, Haraway, 1989; Rose, 1993).

Graphic images which connected the preservation of Vancouver's trees with the preservation of Vancouver's future were evident in brochures such as the January, 1991 public information announcement concerning the proposal of new tree bylaws in the city. In this graphic, the white structure of the tree closely resembles that of a pregnant woman (see figure 1). Inside the pamphlet is another image that shows a tree structure composed of roots or branches inexorably dividing into smaller and smaller limbs. The image resonates as one of connectedness and of natural and organic growth and fecundity through time. ${ }^{20}$

Figure 1: Public information announcement concerning the proposal of new tree bylaws in Vancouver (January 1991).

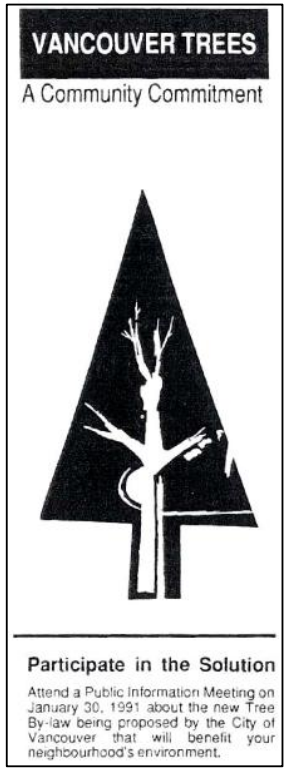

19 Anderson (1991, 11-12) writes of this imagined community: "If nation-states are widely conceded to be 'new' and 'historical', the nations to which they give political expression always loom out of an immemorial past, and, still more important, glide into a limitless future".

${ }^{20}$ Here the feminized feature of landscape production is most evident. The trees that are being protected are coded as female, and contain the "seeds" of the future generation. For further discussion of discourses about community and stewardship and the feminization of nature (see Merchant, 1989; Rose, 1993). 
In contrast with this fecund, pastoral imagery, sojourners and city-dwellers, who lack the direct connection to the past and the soil, are depicted as unable to participate in or even understand the imperative to guide and manipulate the future. As they are rootless (cut off) they can be portrayed as fundamentally [uncaring] of the needs of future generations. Although the majority of those resisting tree removal considered and presented their struggle as one of environmental protection, the aforementioned representations were vivid enough for many developers to contest the movements as racist. As with the monster house controversy, people I interviewed were extremely wary of and concerned about being considered racist. When asked if his organization's resistance to the felling of the two sequoias in April might be construed as racist, Eric Watt said in a newspaper interview, "I don't care who is doing it. If people are doing something that is destructive to the neighborhood, there is going to be a reaction" (quoted in the Vancouver Sun, see Blain, 1990). ${ }^{21}$

Despite Watt's stance, however, the location of the two sequoias on the property of Arnold $\mathrm{Wu}$, a Hong Kong Chinese immigrant and developer, whose daughter, Suzanne $\mathrm{Wu}$, is a prominent real-estate broker doing extensive business with Hong Kong, gave the conflict a racial cast. In many of the newspaper articles on the sequoia cutting and protest actions, the daughter's name was mentioned in connection with the event. During a period of extensive media coverage her Mercedes was vandalized. In Hong Kong, the story was a controversial high-profile news item for over a week, with the clear perception overseas that the resistance protests were racially motivated (Moore, 1997).

Over thirty letters concerning tree management were sent to the Vancouver Planning Department between 1988 and 1990. A majority of the letters came from west-side neighborhoods and indicated a desire for more tree regulation by city officials. ${ }^{22}$ On 7 March 1989, city officials petitioned the province for the authority "to regulate the destruction or removal of trees and for making different regulations for different areas of the city" (R A Rabnett and Associates, 1990, 1). Although the BC provincial government declined to give the city authority over tree-cutting on private lots, city officials initiated new bylaws in early 1991 designed to protect mature trees in RS-1 (single family) neighborhoods. These bylaws drew from a 1990 study by a

${ }^{21}$ Watt was a member of the Granville-Woodlands Property Owners Association (GWPOA), which was one of the main organizations protesting the removal of mature trees on private property. In addition to the GWPOA, there were several other urban community groups protesting the changes in Vancouver's landscape during this time period. These organizations were composed of local area residents, primarily property owners. For more information about these types of organizations, which varied somewhat in style and in their general aims, see Mitchell (1993b), Majury (1990), Ley (1995), and Pettit (1992).

${ }^{22}$ These letters are discussed in the publication, Trees on Single Family Lots: A Program for the Protection of Trees on Private Property (R. A. Rabnett and Associates, 1990). This publication is available in the City of Vancouver Planning Department. 
consultant team of planners, landscape architects, municipal lawyers, and arboriculturalists entitled, Trees on Single Family Lots: A Program for the Protection of Trees on Private Property.

\section{Tree C}

This is a common example of a semi-mature Western Red Cedar (Thuja Plicata) located at 3243 Point Grey Road. The same formula used in the previous case study will be used.

Step 1 Calculation of Basic Value

The diameter at $\mathrm{DBH}$ was 36 ins.

The current $\$$ value is $\$ 40.00$

$$
36 \times 36 \times 0.7854=1017.87 \times \$ 40=\$ 40714 \text { (Basic Value) }
$$

Step 2 Calculation of Species Factor $100 \%$

Step 3 Calculation of Condition Value Factor

Although this tree is a vigorous specimen, it has a rather sparse and slightly tattered crown. The value has been reduced to $80 \%$ of the "Species Factor".

Therefore its "Condition Value Factor"

$$
=\$ 32571
$$

Step 4 Calculation of Location Value Factor $100 \%$

Value of the Tree $=\$ 32571$

Figure 2: The value of a tree (source: R A. Rabnett and Associates, 1990).

In this planning guide "heritage trees" are outlined by neighborhood and by individual tree. In a complex mathematical calculation, specific trees are valued based on the diameter of the tree, the species type, its condition and its location (see figure 2 ). In determining the value of trees in this "objective" manner, the tree debate is removed from the emotionally charged atmosphere of racism described above. By means of "rational" planning instruments and scientific criteria, the value of individual trees are calculated in a separate sphere, one that is abstracted away from the messy contaminations of ideological debate. The effort to foreground "reason" in the struggle can be seen as an attempt to maintain power. The introduction of racism as an element of the debate is an example of "nonreason", and can be dismissed.

What I've described here is one of the many ongoing pedagogical narrations of the nation which are contested by the Hong Kong Chinese immigrants. For example, in the specific disruption to the hegemonic narrative of nations and roots, a group of Chinese executives contested the urban and rootless images of the Hong Kong Chinese with a business fair, which they named, "TRANS/PLANTS: New Canadian Entrepreneurs" (see figure 3). The fair, organized by the Hong Kong-Canada Business Association (HKCBA), featured immigrant entrepreneurs engaged in trading and manufacturing. The intent of the exhibition was to counter the image of Hong Kong Chinese investors as exploitative real-estate speculators by demonstrating the many tangible economic contributions of the Chinese entrepreneurs in areas of the 
productive economy. Real-estate speculation, or "flipping" was a source of great anger for long-term residents, who felt that Hong Kong buyers were interested in houses only for profit, rather than for establishing "roots" in a long-term home. Bruce Wong, the President of the HKCBA, said of the business fair:

B: Because of the newspapers' attacks on Orientals mainly investing in real estate we came out with an exhibition. We didn't invite anybody that's involved in the real estate business. We invited only those people doing manufacturing and trading to participate in this exhibition.

$\mathrm{K}$ : Was it a deliberate attempt to counter the ideology that the media has been presenting?

B: Yes it's a deliberate attempt put out by our organization to counter that situation. To show to the public that there is a group that is doing non real estate (author's interview, 1991).

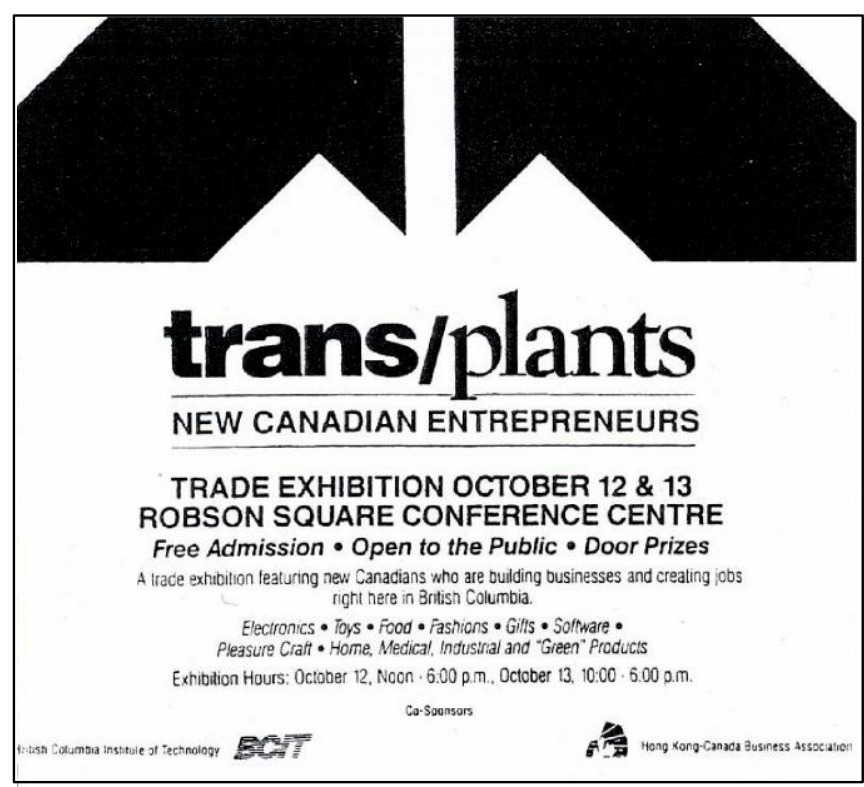

Figure 3: Poster for the business fair TRANS/PLANTS.

The term trans/plant, or transplantation elicits images of displacement in a positive sense, as something that remains viable and alive in a new setting. Rather than uprootedness, which resonates as an unwanted disrupture, it evokes a degree of will, or power in the movement. Malkki (1992, 31) writes of the term "transplantation": "It

strongly suggests, for example, the colonial and postcolonial, usually privileged, category of 'expatriates' who pick up their roots in an orderly manner from the 'mother country,' the originative culture-bed, and set about their 'acclimatization' in the 'foreign environment' or on 'foreign soil' - again, in an orderly manner'. The use of the image of the transplant as a Chinese entrepreneur, rather than a white colonial expatriate, again reverses pre[-]established meanings of nature and normality. "Civilization" is brought from the seedbed of Chinese entrepreneurial capitalism, and deposited to re[-]flower on Vancouver's fertile, but largely untilled, suburban soil. Rather than the pastoral Eden of a preindustrial countryside, "the originative" site is Hong Kong, the original man is Chinese, and the origins of civilization are urban capitalism. 
In this case, the reworking of a roots narrative by Hong Kong businessmen clearly disrupts normative cultural meanings in Vancouver. At the same time, however, it functions as a smooth supplement to an ideology of free trade and free markets. The counternarrative of roots is one that is associated with a narrative of transplanted capitalism; thus the new "inter" national spaces of a "transnational culture" produce the new rooted spaces of capital accumulation.

Other examples of the interconnections between cultural interventions and the furthering of economic ideologies are numerous. Methods of combating the growing racial frictions in late 1980s Vancouver included the appropriation of "positive" Orientalist representations of Chinese by wealthy Hong Kong-Canadian businessmen like Victor Li, Stanley Kwok and David Lam. One of the representations that was consistently promulgated was that of bridge-builder, a subject position in-between nations - literally straddling the Pacific Ocean. Stanley Kwok, the architect for the Vancouver mega-project undertaken by Hong Kong magnate $\mathrm{Li} \mathrm{Ka}$-shing, for example, was recruited by Li to "make Pacific Place happen and, not incidentally, to build bridges between Concord and Vancouver's business establishment." The Vancouver Finance Minister said of Kwok, "Stanley is a terrific bridge between the Chinese and Canadian business communities. He bridges it well and he brings them together, and that's very important" (quoted in Williamson, 1992).

In his discussion of the concept of ambivalence, Bhabha also uses the bridge as a metaphor of ambivalent articulation. In countering the idea of the nation as timeless territory, one whose traditions are separate and autonomous, the bridge is conceptualized as a progressive space in-between. Bhabha writes, quoting Heidegger:

It is in this sense that the boundary becomes the place from which something begins its presencing in a movement not dissimilar to the ambulant, ambivalent articulation of the beyond that I have drawn out: "Always and ever differently the bridge escorts the lingering and hastening ways of men to and fro, so that they may get to other banks. ... The bridge gathers as a passage that crosses" $(1994,5)$.

Here it seems that the bridge metaphor is one of potentially resistant ambivalence. Yet the metaphoric bridges that were discussed by the Finance Minister, Grace McCarthy, in 1992, were heralded because of their potential to join international capitalisms. Those hybrid Chinese-Canadians serving in the position as cultural bridges between communities were celebrated for their ability to further Vancouver's integration into the networks of the global economy, not for their ability to intervene in dominant national narratives. Furthermore, the appropriation of the bridge metaphor has occurred not just from within the western business community and Canadian government, but also from many of the "hybrid" Chinese businessmen themselves. Strategic appropriations of terms and concepts such as "bridgebuilder" have enabled businessmen to colonize the intermediary position between nations and cultures and to operate as the irreplaceable mediating figures of both commerce and culture. 
In Vancouver, for example, other orientalist and self-essentializing representations such as the "model minority" and the "global economic subject" have been made alongside fervent proclamations of cultural Canadianness. Although the ongoing production of orientalism has always required the complicity of Asian elites to some extent (see, for example, Dirlik, 1996), the contemporary tensions between the increasingly unconstricted movements of capital and culture, and the boundaries, institutions, and myths of the nation-state have perhaps made the current moment particularly salient for this type of strategic orientalizing [make sure this term is clear since the introduction of this paper]. As Dirlik has argued, "culturalist essentialism, regardless of its origins in the state or with intellectuals, serves to contain and to control the disruptive consequences of globalization. This helps explain the simultaneous appearance of cultural nationalism with calls for economic globalization" $(1996,115)$. In this sense, the favorable projection of model-minority, hybrid, ChineseCanadian bridgebuilders by both Canadian government officials and Chinese-Canadian businessmen themselves serves to advance the idea of "multiculturalism" as a national value-system and ideological force at the same time that it furthers capitalist integration. This is similar to the move in some Asian societies such as Singapore and Malaysia, of advancing Confucianism as the source of both national ethics and economic success. ${ }^{23}$

In Vancouver in the 1980s, the orientalist coding of the Chinese model minority and economic middleman was advanced as a kind of counternarrative to the exclusive framing of local knowledge and cultural citizenship such as were manifest in the various struggles over monster houses and the removal of trees. ${ }^{24}$ This positioning was promulgated in Vancouver during a period of great upheaval and racial conflict in the city following the purchase of a large chunk of downtown real estate by the Hong Kong developer, Li Ka-shing. During this period, Li's son, Victor Li, held several interviews with local and national newspapers in which he declared himself a "good Canadian" and his company, "a good blue-chip Canadian company" (quoted in Fletcher, 1989). Li's attempts to position himself in a site in-between the narratives of

${ }^{23}$ Former Singapore Prime Minister Lee Kuan Yew, for example, recently promoted the term "neotraditional modernity" when describing the foundations of Singapore's economic success. Lee locates the Confucian revival and Chinese cultural values in general as the best framework for both the legitimacy of the nation-state and the continuation of the economic "miracle". For a further discussion see Wee (1996).

${ }^{24}$ By cultural citizenship I am referring to the sphere of cultural rights people possess and exercise that are frequently independent from formal membership in the state. The idea of the constitution of different citizenships is discussed in more detail in Holston and Appadurai (1996, 190191). For a discussion of the ongoing exclusion of the Asian subject from cultural citizenship in the American context, see Lowe (1996, especially 1-36). 
the model minority and the acculturated Canadian citizen occurred at a time of increasing capital connections between Hong Kong and Vancouver.

Clearly, the ultimate flexibility of this self-fashioning process is useful in the contemporary global economy. As capitalist networks articulate, Chinese businessmen who speak the language of the global economic subject, but are also imbricated in a Hong Kong Chinese discourse, are able to operate as the quintessential hybridized middlemen (Ong, 1996, 1993). With flexible citizenship and deterritorialized systems of credit, but with a durable and elastic business network established on the basis of the extended family (see Mitchell, 1995), overseas Hong Kong Chinese capitalists can manipulate images of both the transnational, transcultural cosmopolitan and the "ethnic Chinese", enabling them to position themselves on the margins of the nation, but at the lucrative center of Pacific Rim business.

In conclusion, I suggest that the contemporary celebration of the disruptive qualities of diasporic identity, hybridity, and third spaces is premature. Although there is clearly the potential for resistance to hegemonic narratives of nation and race in these positionings, there is also the potential for collaboration in the hegemonic narratives of capitalism. In-between spaces and subject positions are produced in the context of economic as well as cultural processes and must be theorized in tandem. Theories which privilege the cultural spaces of the nation, and which continually render those spaces abstract, may neglect the actual geographies of capital accumulation in which those spaces are produced. Furthermore, the decontextualized use of terms such as hybridity and diaspora, which in theory provide exciting disruptions of national and cultural narratives, in practice can be and are often appropriated for projects furthering various economic agendas. It is the fetishization of these terms that allows for their quick appropriation; in order to ensure more progressive meanings the concepts must be historically and geographically located. This type of theorizing, one which is embedded in specific histories and maps, enables a richer comparative understanding of processes and events, and avoids the kinds of slippages and abstract spatial metaphors so common to literary criticism and cultural studies.

\section{References}

Adorno, T. W. and M. Horkheimer. 1989. Dialectic of Enlightenment. Trans. J. Cumming. New York: Continuum.

Anderson, B. 1991. Imagined Communities: Reflections of the Origin and Spread of Nationalism. London: Verso.

Bhabha, H. 1994. The Location of Culture. New York: Routledge.

Bhabha, H. 1990. Nation and Narration. New York: Routledge. 
Canetti, E. 1978. Crowds and Power. Trans. Carol Stewart. New York: Seabury Press.

Clifford, J. 1992. Traveling cultures. In, L. Grossberg, C. Nelson \& P. Treichler (eds.), Cultural Studies. New York: Routledge, pp. 96-112.

Clifford, J. 1994. Diasporas. Cultural Anthropology 9, 302-38.

Deleuze, G. and F. Guattari. 1987. A Thousand Plateaus. Trans. B. Massumi. Minneapolis: University of Minnesota Press.

Dirlik, A. 1996. Chinese history and the question of Orientalism. History and Theory 35(4), 96-118.

Duncan, J. and N. Duncan. 1984. A cultural analysis of urban residential landscapes in North America: The case of the anglophile elite. In, J. Agnew, J. Mercer \& D. Sopher (eds.), The City in Cultural Context. Boston: Allen and Unwin, pp. 255-76.

Gilroy, P. 1993. The Black Atlantic: Modernity and Double Consciousness. London: Verso.

Gilroy, P. 1992. Cultural studies and ethnic absolutism. In, L. Grossberg, C. Nelson \& P. Treichler (eds.), Cultural Studies. New York: Routledge, pp. 187-98.

Haraway, D. 1989. Primate Visions. New York, Routledge.

Holston, J. and A. Appadurai. Cities and citizenship. Public Culture 8(2), 187-204.

Kolodny, A. 1975. The Lay of the Land: Metaphor as Experience and History in American Life and Letters. Chapel Hill: University of North Carolina Press.

Lavie, S. and T. Swedenburg. 1996. Displacement, Diaspora, and Geographies of Identity. Durham: Duke University Press.

Lee, Q. 1994. Delineating Asian (Hong Kong) intellectuals: Speculation on intellectual problematics and post/coloniality. Third Text 26, 11-23.

Ley, D. 1995. Between Europe and Asia: The case of the missing sequoias. Ecumene 2, 185210.

Lowe, L. 1996. Immigrant Acts. Durham: Duke University Press.

Majury, N. 1990. Identity, Place, Power and the "Text": Kerry's Dale and the "Monster" House. MA thesis, Department of Geography, University of British Columbia, Vancouver.

Malkki, L. 1992. National Geographic: The rooting of peoples and the territorialization of national identity among scholars and refugees. Cultural Anthropology 7, 24-44. 
Merchant, C. 1989. The Death of Nature: Women, Ecology and the Scientific Revolution. New York: Harper and Row.

Mitchell, K. 1997a. Conflicting geographies of democracy and the public sphere in Vancouver, B.C. Transactions of the Institute of British Geographers 22 (2), 162-79.

Mitchell, K. 1997b. Fast capital, race, modernity and the monster house. In, R. George, (ed), Burning Down the House: Recycling the Domestic. Colorado: Westview Press, pp. 187211.

Mitchell, K. 1995. Flexible circulation in the Pacific Rim: Capitalisms in cultural context. Economic Geography 71, 364-82.

Mitchell, K. 1993a. Multiculturalism, or the united colors of capitalism? Antipode 25, 263-94.

Mitchell, K. 1993b. Facing Capital: Cultural Politics in Vancouver. PhD. dissertation, Department of Geography, University of California, Berkeley, CA.

Moore, D. 1997. Remapping resistance: ground for struggle and the politics of place. In, S. Pile \& M. Keith (eds.), Geographies of Resistance. London: Routledge, pp. 87-106.

Olds, K. 1995. Globalization and the production of new urban spaces: Pacific Rim megaprojects in the late 20th century. Environment and Planning A 27, 1713-43.

Ong, A. 1996. Chinese modernities: the narratives of nation and capitalism in the Asia-Pacific. In, A. Ong \& D. Nonini, (eds.), Ungrounded Empires: The Cultural Politics of Modern Chinese Transnationalism. New York: Routledge, pp. 171-202.

Ong, A. 1993. On the edge of empires: Flexible citizenship among chinese in diaspora. Positions 3, 745-778.

Pettit, B. 1992. Zoning, the Market and the Single Family Landscape: Neighborhood Change in Vancouver, Canada $\mathrm{PhD}$. dissertation, Department of Community and Regional Planning, University of British Columbia, Vancouver.

Poster, M. 1990. Mode of Information: Postructuralism and Social Context. Cambridge: Polity Press.

Pred, A. 1990. Lost Words and Lost Worlds: Modernity and the Language of Everyday Life in Late Nineteenth Century Sweden. Cambridge: Cambridge University Press.

R. A. Rabnett and Associates. 1990. Trees on Single Family Lots: A Program for the Protection of Trees on Private Property. R. A. Rabnett and Associates, 1290 Homer Street, Vancouver, BC, Canada, V6B 2 Y5.

Rose, G. 1993. Feminism and Geography: The Limits of Geographical Knowledge. Minneapolis: University of Minnesota Press. 
Safran, W. 1991. Diasporas in modern societies: Myths of homeland and return. Diaspora 1, 83-99.

Said, E. 1989. Culture and Imperialism. New York: Vintage Books.

Schaffer, K. 1990. Women and the Bush: Forces of Desire in the Australian Cultural Tradition. Cambridge: Cambridge University Press.

Soja, E. 1996. Thirdspace: Journeys to Los Angeles and Other Real-and-Imagined Places. Cambridge: Blackwell.

Sparke, M. 1996. Negotiating Nation-States: North American Geographies of Culture and Capitalism. PhD. dissertation, Department of Geography, University of British Columbia, Vancouver.

Taylor, C. 1991. From saving trees to a broad, mushy intrusion into every single family lot. Vancouver Sun, 21 January, page A2.

Theweleit, K. 1987. Male Fantasies, Volume 1. Women, Floods, Bodies, History. Trans. S. Conway. Minneapolis: University of Minnesota Press.

Usinger, M. 1990. Huge trees threatened. Courier, 11 March, page 1.

Wee, C. J. W-L. 1996. Staging the new Asia: Singapore's Dick Lee, pop music, and a countermodernity. Public Culture 8, 489-510.

Willems-Braun, B. 1997. Buried epistemologies: The politics of nature in (post)colonial British Columbia. Annals of the Association of American Geographers 87, 3-31.

Williams, R. 1973. The Country and the City. London: Chatto and Windus.

Williamson, R. 1992. Kwok’s connections open doors to Asia. Globe and Mail, 6 April, page B1.

Young, R. 1995. Colonial Desire: Hybridity in Theory, Culture and Race. New York: Routledge. 